\title{
Comparative removal of naphthalene by adsorption on different sand/bentonite mixtures
}

\author{
S. Rennane ${ }^{1^{*}}$, N. Bendjaballah-Lalaoui ${ }^{1}$, M. Trari ${ }^{2}$ \\ ${ }^{1}$ Laboratory of Catalytic Materials and Catalysis in Organic Chemistry, Faculty of Chemistry (USTHB) BP 32 El-Alia \\ 16111, Algiers, Algeria \\ ${ }^{2}$ Laboratory of Storage and Valorization of Renewable Energies, Faculty of Chemistry (USTHB), BP 32, 16111, Algiers, \\ Algeria
}

Received June 26, 2018, Revised March 12, 2019

The purpose of this study was to advance the understanding of naphthalene (polycyclic aromatic hydrocarbon) adsorption on sand/bentonite mixtures in the context of their use in the lining of waste disposal facilities. Batch adsorption studies were carried out to estimate the adsorption capacities of sand/bentonite mixtures. Different percentages of the bentonite $(0 \%$ to $12 \%)$ in sand/bentonite mixtures were tested. These mixtures were characterized by X-ray diffraction (XRD), scanning electron microscopy (SEM), and Fourier transform infrared spectroscopy (FTIR). It was found that the mixture with $2 \%$ of bentonite adsorbs the highest amount of naphthalene over the whole range of initial naphthalene concentrations studied $\left(\mathrm{C}_{0}: 2.5-22 \mathrm{mg} \mathrm{L}^{-1}\right)$; this optimal fraction was therefore selected. The effect of the initial naphthalene concentration, percentage of the bentonite in the sand/bentonite mixture and temperature on the adsorption was investigated. The adsorption isotherms, established for every percentage of bentonite, revealed that the naphthalene adsorption follows a linear Freundlich isotherm for the optimal fraction of bentonite (2\%). The kinetic study showed that the process obeys a pseudo-second-order equation model. The thermodynamic parameters $\left(\Delta \mathrm{G}^{\circ}\right.$, $\Delta \mathrm{H}^{\circ}$, and $\Delta \mathrm{S}^{\circ}$ ) indicated an endothermic and spontaneous nature of the naphthalene adsorption. The adsorption of naphthalene is more favorable at high temperatures and activation energy $\left(8.263 \mathrm{~kJ} \mathrm{~mol}^{-1}\right)$ suggests a physical adsorption.

Keywords: Adsorption; Naphthalene; Bentonite; Sand/bentonite mixture.

\section{INTRODUCTION}

As the world population grows, the industrialization increases, thus generating more wastes and pollutants. Polycyclic aromatic hydrocarbons (PAHs), such as naphthalene, are among the most widespread organic pollutants and occur both naturally (in volcanic eruptions and forest fires) and by anthropogenic activities. Most PAHs emissions result from incomplete combustion of fossil fuels, and vehicle exhaust [1, 2]. The sources of naphthalene discarded in aquatic environment include industrial and domestic wastewaters, leakage of PAHs-containing materials, like petroleum fractions, creosote and pharmaceutical waste [3]. The US Environmental Protection Agency (U.S.E.P.A) has classified naphthalene as a hazardous pollutant for its carcinogenic and mutagenic effects for humans [4]. Hence, various methods for removing naphthalene from aqueous solutions including photocatalytic oxidation [5], biodegradation using surfactants [6], electron beam irradiation [7], ozonation [8], adsorption using zeolites [9] and activated carbon [10-12] have been reported. The adsorption process is known for its simplicity, low-cost and insensitivity to toxic substances [11]; it is also applied in active barriers in the soil remediation.
The most common forms of groundwater remediation are physical containment and pumpand-treat methods and both methods are expensive [13]. The natural materials widely used in liner applications are clays and sand/bentonite mixtures. Soil liners are preferred because of their low cost, large leachate attenuation capacity and resistance to damage and perforations [15]. The use of clays as liner materials has been applied over the last few decades [16, 17]. Recently Lamichhane et al. [18] published a review gathering several adsorbents such as modified clay minerals used to remove PAHs from aqueous solutions and documented in 150 papers.

Bentonite (mainly montmorillonite) is the most preferable clay mineral for barrier applications due to its high surface area, cation-exchange capacity, large swelling potential, and low hydraulic conductivity to water [19]. Bentonite is 2:1 mineral with one alumina octahedral sheet and two silica sheets, which form layers held together by Van der Waals forces [20]. Most studies have shown that natural or modified bentonite is an effective adsorbent for heavy metals [21, 22] and toxic compounds such as phenol and related compounds $[23,24]$, as well as naphthalene $[25,26]$.

* To whom all correspondence should be sent:

E-mail: samira_rennane@yahoo.fr 
S. Rennane et al.: Comparative removal of naphthalene by adsorption on different sand/bentonite mixtures

Sand/bentonite mixtures represent efficient barriers for removing contaminants. It is possible to vary their proportions in order to combine the advantages of both materials: the waterproofing capacity of bentonite associated with the relatively high shear strength typical of sand [27].

Kenney et al. [28] proposed the sand/bentonite mixture as an alternative material to the clay liners. Staninska et al. [29] have studied the sorption of phenanthrene onto sand/bentonite mixtures. The amount of bentonite is varied in the range $(1.25 \%-5 \%)$. The authors have demonstrated that the increase in sorption efficiency is less pronounced at high bentonite percentages. Also, the compacted bentonite (3\%) could achieve a hydraulic conductivity of $10^{-7} \mathrm{~cm} \mathrm{~s}^{-1}$ which is a regular recommended value for the construction of hydraulic barriers [19]. Large clay deposits exist in the Northwest of Algeria (Mostaganem and Maghnia) with significant recoverable reserves of bentonite. The choice of the bentonite percentage range $(0-12 \%)$ is based on previous works [30] since lower percentages do not have real applications in the construction of barriers.

The effects of bentonite fractions and initial concentration of naphthalene on the adsorption were analyzed to optimize the percentage of bentonite which better removes naphthalene. The Langmuir and Freundlich isotherms, kinetic models (pseudofirst-order, pseudo-second-order, Elovich and intraparticle diffusion models) were adopted to investigate the mechanism of naphthalene adsorption on the mixture sand/bentonite $(2 \%)$; the thermodynamic parameters were also calculated.

\section{MATERIALS AND METHODS}

\section{Preparation of naphthalene solution}

Due to the low water solubility $\left(26.54 \mathrm{mg} \mathrm{L}^{-1}\right.$ at $20 \pm 2{ }^{\circ} \mathrm{C}$ ) of naphthalene (Sigma Aldrich, USA, 99\% purity), a water-methanol (Sigma Aldrich, $99.7 \%$ purity) solution was used. Methanol is a good solvent to enhance the adsorption of non-polar compounds, such as naphthalene. A stock solution (30 $\mathrm{mg} \mathrm{L}^{-1}$ ) was prepared by dissolving $30 \mathrm{mg}$ of naphthalene in $20 \mathrm{~mL}$ of methanol, diluted to $1 \mathrm{~L}$ with distilled water and stored in airtight glass bottles in the dark at room temperature. The various solutions of naphthalene $\left(2.5-22 \mathrm{mg} \mathrm{L}^{-1}\right)$ were prepared by diluting the stock solution with watermethanol solution ( $2 \%$ vol. methanol). Low amounts of methanol (up to 5\% vol.) do not modify the sorption properties of both naphthalene and phenanthrene [31].

\section{Preparation of the adsorbent}

The adsorbent used in this study was the mixture sand/bentonite. Sand comes from a petroleum region (Hassi Messaoud, Southern Algeria) (Table 1); while bentonite comes from Western Algeria (Maghnia). It is natural clay marketed by the National Company of Non-Ferrous Mineral Products BENTAL Factory, located in Maghnia (Table 2). The sand was previously washed to eliminate all impurities, and then dried at $105^{\circ} \mathrm{C}$ for $24 \mathrm{~h}$.

The bentonite was dried at $50^{\circ} \mathrm{C}$ for $48 \mathrm{~h}$ and used at ratios of $0 \%, 2 \%, 6 \%, 8 \%$ and $12 \%$.

\section{Experimental characterization techniques}

The sand/bentonite mixtures were characterized by various techniques. X-ray diffraction (XRD) was performed to confirm the phases obtained after mixing. A PANalytical diffractometer equipped with a $\mathrm{Cu}$ anticathode $(\lambda \mathrm{K} \alpha=1.541874 \AA)$ at a working voltage of $40 \mathrm{kV}$ and a current intensity of $30 \mathrm{~mA}$ was used. The interaction between sand and bentonite was investigated by scanning electron microscope (SEM) using the JEOL JSM 6830 system equipped with an energy-dispersive spectrometer (EDS). The FTIR spectra of sand/bentonite mixtures were determined on a JASCO FT/IR-4600 model. All standards and various sand/bentonite mixture samples were prepared using $\mathrm{KBr}$ technique.

\section{Batch sorption experiments}

Batch experiments were carried out in $250 \mathrm{~mL}$ Erlenmeyer flasks, $1 \mathrm{~g}$ of adsorbent (sand/bentonite mixture) was immersed in $100 \mathrm{~mL}$ of naphthalene solutions $\left(2.5-22 \mathrm{mg} \mathrm{L}^{-1}\right)$. The flasks were shaken at $500 \mathrm{rpm}$, allowing sufficient time $(30 \mathrm{~min})$ for the adsorption equilibrium. The effect of temperature was studied at 10,20 and $30^{\circ} \mathrm{C}$ at natural $\mathrm{pH}$. The residual naphthalene concentration was determined by UV-visible spectrophotometry (Shimadzu, UV 1800) at the maximum wavelength $\left(\lambda_{\max }=277 \mathrm{~nm}\right)$. The amount of adsorbed naphthalene $\mathrm{q}_{\mathrm{t}}\left(\mathrm{mg} \mathrm{g}^{-1}\right)$ at a given time $\mathrm{t}$, was calculated as follows:

$$
\mathrm{q}_{\mathrm{t}}=\frac{\left(\mathrm{C}_{0}-\mathrm{C}_{\mathrm{t}}\right)}{\mathrm{W}} \mathrm{V}
$$

where $\mathrm{C}_{o}$ and $\mathrm{C}_{\mathrm{t}}$ are the initial and residual concentrations of naphthalene $\left(\mathrm{mg} \mathrm{L}^{-1}\right)$ in solution, respectively; $\mathrm{V}$ the volume of solution $(\mathrm{L})$ and $\mathrm{W}$ the mass of dry adsorbent $(\mathrm{g})$. 


\section{S. Rennane et al.: Comparative removal of naphthalene by adsorption on different sand/bentonite mixtures}

RESULTS AND DISCUSSION

Characterization of the adsorbent

The properties of sand and bentonite are reported in Tables 1 and 2. The results show that the Hassi Messaoud sand contains a low percentage of organic carbon and a high percentage of sand, indicating that it is very clean and hence can be used as reference (Table 1).
The $\mathrm{SiO}_{2} / \mathrm{Al}_{2} \mathrm{O}_{3}$ ratio is 4.04 and the percentage of sodium is higher than that of calcium. It reveals that Maghnia bentonite is sodic montmorillonite [32]. The high value of the specific surface area of Maghnia bentonite (Table 2) indicates that the naphthalene adsorption on sand/bentonite mixtures is mainly controlled by bentonite. Details concerning the characteristics of bentonite were reported by Debieche and Kaoua [30].

Table 1. Hassi Messaoud sand properties.

\begin{tabular}{ccccccc}
\hline $\begin{array}{c}\text { Particles } \\
<80 \mathrm{~m} \\
(\%)\end{array}$ & $\begin{array}{c}\text { Sand particles } \\
(1-0.2 \mathrm{~mm}) \\
(\%)\end{array}$ & $\begin{array}{c}\text { Sand particles } \\
(0.2-0.8 \mathrm{~mm}) \\
(\%)\end{array}$ & $\begin{array}{c}\text { Specific } \\
\text { density } \\
\left(\mathrm{g} \mathrm{L}^{-1}\right)\end{array}$ & $\begin{array}{c}\text { Total } \\
\text { organic } \\
\mathrm{C}(\%)\end{array}$ & $\begin{array}{c}\text { Equivalent } \\
\text { of sand } \\
(\%)\end{array}$ & $\mathrm{pH}$ \\
\hline 1.72 & 94 & 4.28 & 2640 & 0.014 & 93 & 7.64 \\
\hline
\end{tabular}

Table 2. Maghnia bentonite properties [30].

\begin{tabular}{lcccccccccccc}
\hline $\begin{array}{l}\text { Parti- } \\
\text { cles } \\
<80 \mu \mathrm{m} \\
(\%)\end{array}$ & $\begin{array}{c}\text { Parti- } \\
\text { cles } \\
<2 \mu \mathrm{m} \\
(\%)\end{array}$ & $\begin{array}{c}\text { Speci- } \\
\text { fic area } \\
\left(\mathrm{m}^{2} \mathrm{~g}^{-1}\right)\end{array}$ & $\begin{array}{c}\text { Water } \\
\text { content } \\
(\%)\end{array}$ & $\mathrm{pH}$ & $\begin{array}{c}\mathrm{SiO}_{2} \\
(\%)\end{array}$ & $\begin{array}{c}\mathrm{Al}_{2} \mathrm{O}_{3} \\
(\%)\end{array}$ & $\begin{array}{c}\mathrm{CaO} \\
(\%)\end{array}$ & $\begin{array}{c}\mathrm{Na}_{2} \mathrm{O} \\
(\%)\end{array}$ & $\begin{array}{c}\mathrm{Fe}_{2} \mathrm{O}_{3} \\
(\%)\end{array}$ & $\begin{array}{c}\mathrm{K}_{2} \mathrm{O} \\
(\%)\end{array}$ & $\begin{array}{c}\mathrm{TiO}_{2} \\
(\%)\end{array}$ & $\begin{array}{c}\mathrm{MgO} \\
(\%)\end{array}$ \\
\hline 100 & 42.5 & 394 & 8.5 & 10.5 & 64.98 & 16.08 & 0.61 & 3.88 & 2.93 & 2.02 & 0.20 & 3.51 \\
\hline
\end{tabular}

\section{$X R D$ results}

As expected, the powder XRD patterns of the sand/bentonite mixtures (Fig. 1) show the presence of silica $\mathrm{SiO}_{2}$ as the main phase of the sand and alumina $\mathrm{Al}_{2} \mathrm{O}_{3}$ as a minor phase coming from the bentonite present at low percentages $(<12 \%)$. All peaks are indexed according to the JCPDS Cards $\mathrm{N}^{\circ}$ 46-1045and $\mathrm{N}^{\circ} 17-3014$. Such result agrees with the nominal composition of the system sand/bentonite.

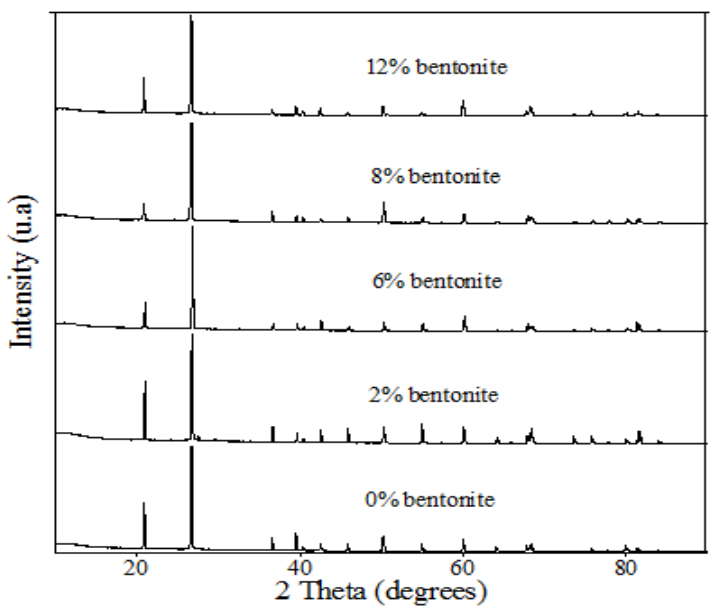

Fig. 1. XRD diffraction pattern of the various sand/bentonite mixtures.

\section{SEM/EDS results}

Firstly, we noted that the grain sizes of the sand in the range $(50-200 \mu \mathrm{m})$ are not homogeneous (Fig. 2a) and the bentonite content increases in the mechanical mixture (sand/bentonite). The sand grains are covered with the bentonite whose size averages $1 \mu \mathrm{m}$. However, a part of the bentonite with a large diameter $(\sim 50 \mu \mathrm{m})$ is also present in the intergranular space of the sand (Fig. 2b, c). The bentonite located both on the sand grains and in the interstitial space is identified via EDS analysis (Fig. 3 and Table 3 ).

In summary, the structural analysis reveals a large covering of sand grains with a high percentage of bentonite. This could lead to a decrease in the adsorption efficiency due to the agglomeration of bentonite grains, thus reducing the accessibility to the adsorption sites.

\section{FITR results}

The spectral analysis for the sand/bentonite mixtures $(0 \%, 2 \%, 6 \%$, and $12 \%)$, illustrated in Figure 4 and Table 4, permits to distinguish three main regions: the elongation bands of $\mathrm{OH}$ groups of water are visible in the region $\left(3800-3300 \mathrm{~cm}^{-1}\right.$ ) while the deformation bands related to $\mathrm{O}-\mathrm{H}$ elongation of water absorbed onto the bentonite are in the region $\left(1730-1340 \mathrm{~cm}^{-1}\right)$. However, the intensity of bands is very low due to negligible absorption of humidity by the various sand/bentonite mixtures, attributed to the high content of sand in these mixtures.

The region $\left(1340-840 \mathrm{~cm}^{-1}\right)$ corresponds to the $\mathrm{Si}-\mathrm{O}$ valence vibration in a tetrahedral site while the region $\left(840-610 \mathrm{~cm}^{-1}\right)$ is assigned to the deformation vibration of $\mathrm{Al}-\mathrm{OH}$ bond groups. The bands $\left(610-400 \mathrm{~cm}^{-1}\right)$ are attributed to the angular deformation of the $\mathrm{Si}-\mathrm{O}-\mathrm{Al}$ unit. 

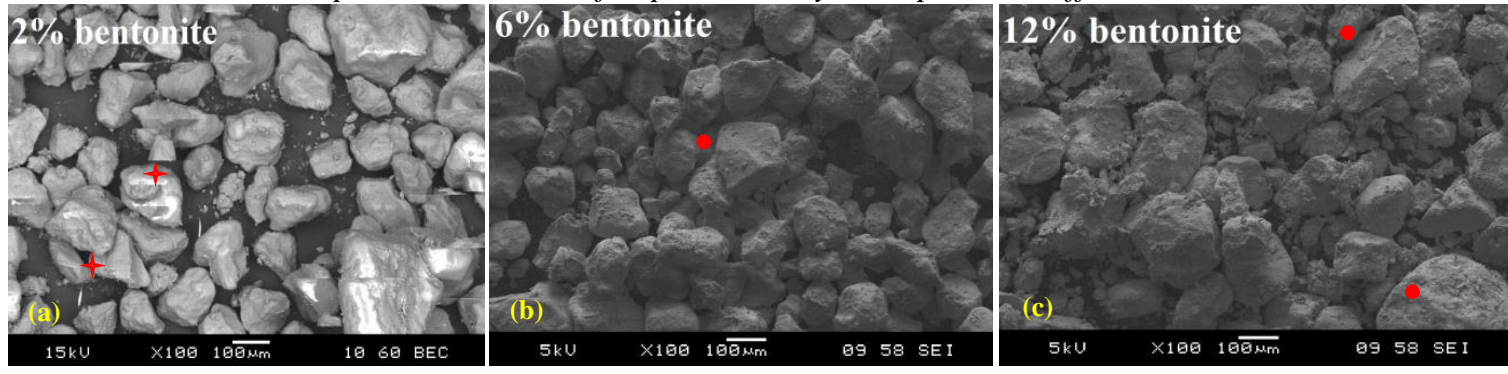

Fig. 2. SEM micrographs showing the dispersion of the bentonite in the mixture sand/bentonite. + Bentonite aggregate - Upholstering sand grains by bentonite

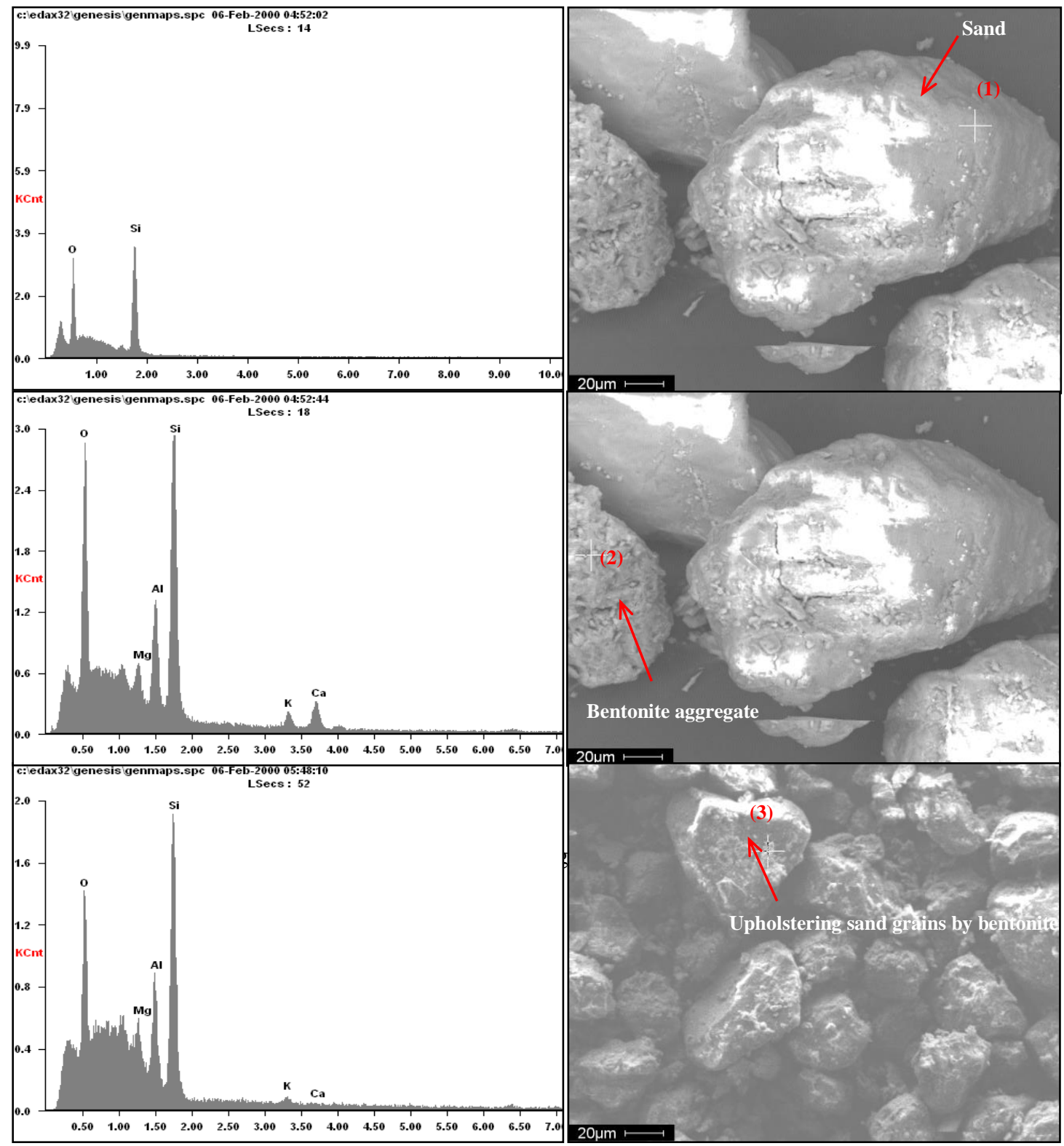

Fig. 3. EDS results and SEM micrographs for sand and bentonite.

Table 3. EDS analysis results obtained for the three positions depicted in Figure 3.

\begin{tabular}{ccccccc}
\hline & \multicolumn{7}{c}{ Wt.\% } \\
\cline { 2 - 7 } Zone & $\mathrm{O}$ & $\mathrm{Mg}$ & $\mathrm{Al}$ & $\mathrm{Si}$ & $\mathrm{K}$ & $\mathrm{Ca}$ \\
\hline 1 & 59.44 & - & - & 40.56 & - & - \\
2 & 54.36 & 01.82 & 08.45 & 29.14 & 02.07 & 4.16 \\
3 & 44.54 & 08.95 & 12.78 & 32.48 & 00.99 & 00.26 \\
\hline
\end{tabular}




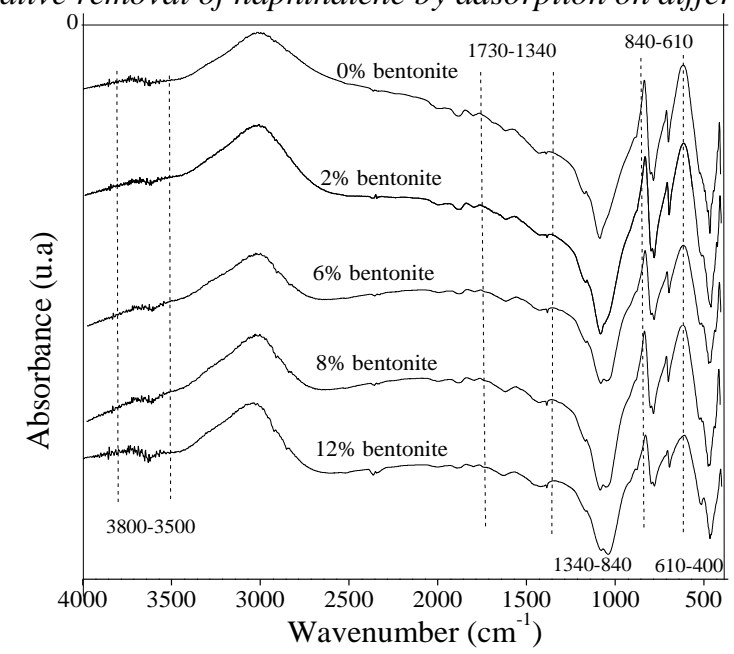

Fig. 4. FITR spectra of the sand/bentonite mixtures.

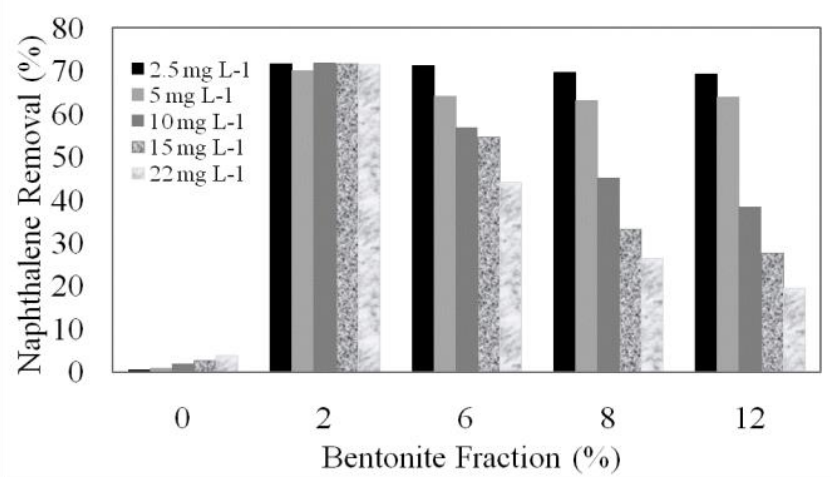

Fig. 5. Optimal fraction of bentonite at different initial concentrations of naphthalene.

Table 4. FTIR analysis results obtained for the various sand/bentonite mixtures.

\begin{tabular}{ccccc}
\hline Frequency & OH & Si-O-Si & Al-OH & Si-O-Al \\
\hline Sand & $3625 / 1617-1420$ & 1082 & $782-690$ & 458 \\
$2 \%$ & $3627 / 1612-1425$ & 1081 & $775-687$ & 452 \\
$6 \%$ & $3631 / 1622-1427$ & 1078 & $777-692$ & 461 \\
$8 \%$ & $3630 / 1613-1429$ & 1080 & $778-694$ & 460 \\
$12 \%$ & $3650 / 1630-1425$ & 1073 & $780-696$ & 463 \\
\hline
\end{tabular}

\section{Optimal fraction of bentonite}

To evaluate the optimal fraction of the bentonite $(0 \%, 2 \%, 6 \%, 8 \%$ and $12 \%)$ in the sand, experiments were carried out under the above conditions. The adsorption efficiency of naphthalene (E) on the sand/bentonite mixtures was calculated as follows:

$$
\mathrm{E}=\frac{\mathrm{C}_{0}-\mathrm{C}_{\mathrm{e}}}{\mathrm{C}_{0}} \times 100
$$

where: $\mathrm{C}_{\mathrm{o}}\left(\mathrm{mg} \mathrm{L}^{-1}\right)$ and $\mathrm{C}_{\mathrm{e}}\left(\mathrm{mg} \mathrm{L}^{-1}\right)$ are the initial and equilibrium liquid-phase concentrations of naphthalene, respectively.

Figure 5 shows that the naphthalene removal efficiency on pure sand ( $0 \%$ of bentonite) is negligible (maximum value $3.84 \%$ ). The optimal naphthalene adsorption (71\%) is obtained at low initial naphthalene concentration $\mathrm{C}_{\mathrm{o}}\left(2.5 \mathrm{mg} \mathrm{L}^{-1}\right)$ for all bentonite percentages. This result can be attributed to the mobility of the reaction medium, which is amplified at low concentrations, thereby promoting the adsorption. At $2 \%$ bentonite, the optimum adsorption efficiency is conserved independently of the concentration $\mathrm{C}_{\mathrm{o}}$. This is due to the good dispersion of the bentonite particles on the external sand surface, allowing a great accessibility to active sites. By contrast, at $6 \%, 8 \%$ and $12 \%$ of bentonite, the adsorption efficiency decreases with increasing the concentrations $C_{0}$. This is due to the increase in resistance to the transfer of solute molecules from the solution toward the external surface of the adsorbent, generated by the large concentrations of naphthalene $\mathrm{C}_{0}$. On the other hand, the reduction of active sites is caused by the agglomeration of bentonite particles related to the texture of the 


\section{S. Rennane et al.: Comparative removal of naphthalene by adsorption on different sand/bentonite mixtures} latter. Ge et al. [33] have studied the adsorption of naphthalene on activated carbon modified with nitric acid using microwave radiation and obtained a removal efficiency of $92 \%$ while Agarry et al. [3] found that the removal efficiency of naphthalene onto spent tea leaves reached $96 \%$.

\section{Effect of initial concentration and percentage of bentonite on the sand/bentonite mixtures}

The initial concentration of the adsorbate $\mathrm{C}_{\mathrm{o}}$ is an important factor which significantly affects the adsorption. The adsorbed amount of naphthalene onto the sand/bentonite mixtures at different concentrations $\mathrm{C}_{\mathrm{o}}\left(2-22 \mathrm{mg} \mathrm{L}^{-1}\right)$ is shown in Figure 6. The sorption is rapid in the initial stage and gradually decreases with the progress of sorption until equilibrium is reached. At $2 \%$ and $6 \%$ of bentonite, the equilibrium is very fast $(6 \mathrm{~min})$ for concentrations above $10 \mathrm{mg} \mathrm{L}^{-1}$, while above and below this concentration, the equilibrium time lies between 12 and $20 \mathrm{~min}$. At 8 and 12\% of bentonite, the equilibrium is rapidly reached ( 3 to $6 \mathrm{~min}$ ) over the whole concentrations range. The longer
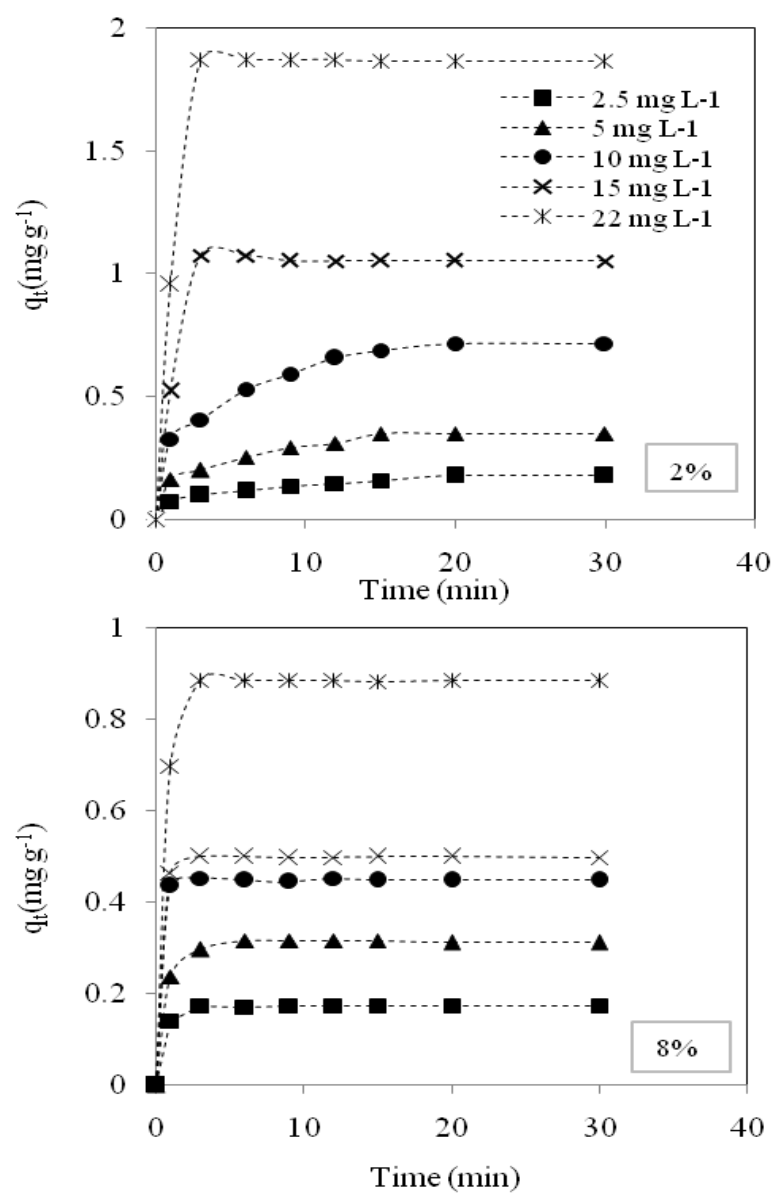

equilibrium time obtained with $2 \%$ bentonite (optimal fraction) revealed that the adsorption process is long due to the probable existence of an intraparticle transfer of naphthalene molecules. This result will be verified subsequently in the kinetic study of the adsorption process.

The adsorbed amount of naphthalene on the sand/bentonite mixtures increases with increasing the concentration $\mathrm{C}_{\mathrm{o}}$ (Fig. 6) and decreases with the bentonite percentage. The maximum adsorbed amounts of naphthalene, at $\mathrm{C}_{\mathrm{o}}$ of $22 \mathrm{mg} \mathrm{L}^{-1}$, are $1.57,0.97,0.58$, and $0.43 \mathrm{mg} \mathrm{g}^{-1}$ for bentonite percentages of $2 \%, 6 \%, 8 \%$ and $12 \%$, respectively.

The positive effect of the concentration $\mathrm{C}_{\mathrm{o}}$ on the adsorbed amount by using other adsorbents has been reported in the literature. Agarry et al. [3] indicated an increase in the naphthalene adsorption onto spent tea leaves with raising the initial concentrations while Sener and Ozy1lmaz [34] found the same trend for the adsorption of naphthalene on sonicated talc.
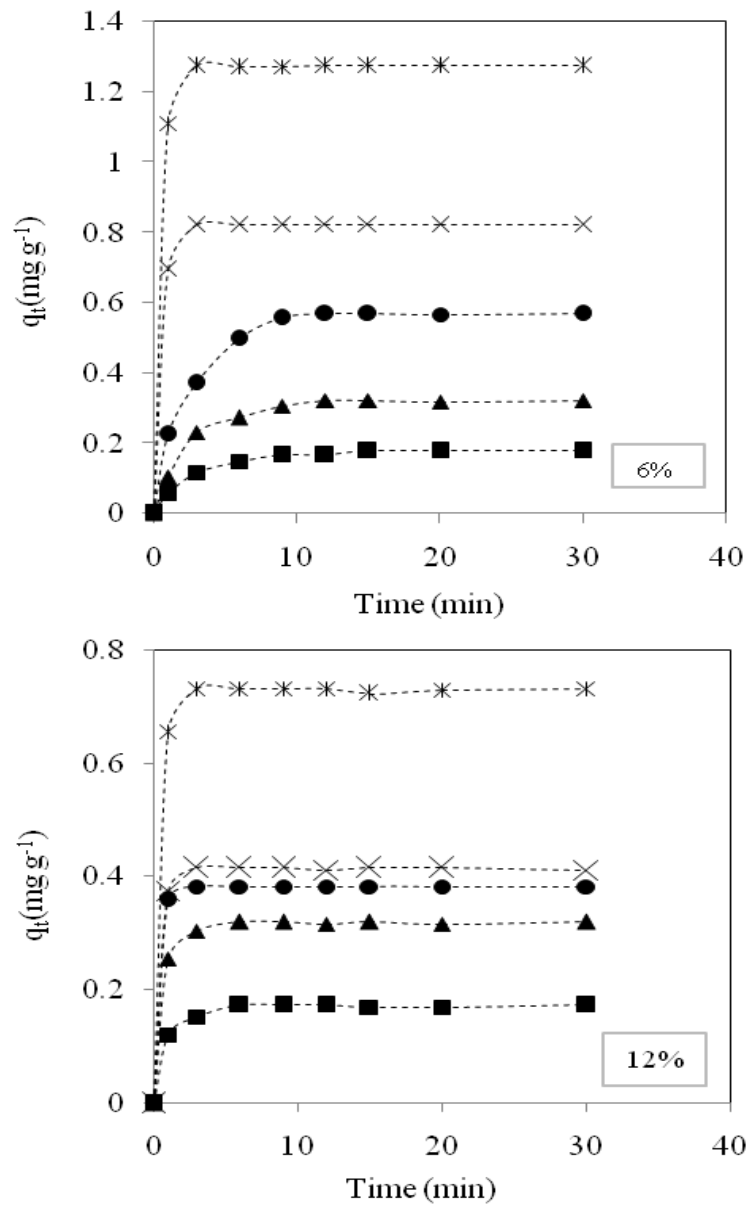

Fig. 6. Effect of the initial concentration on naphthalene adsorption onto sand/bentonite mixtures. 
S. Rennane et al.: Comparative removal of naphthalene by adsorption on different sand/bentonite mixtures

Table 5. Isotherm model parameters for adsorption of naphthalene onto sand/bentonite mixtures.

\begin{tabular}{|c|c|c|c|c|c|}
\hline \multirow{2}{*}{ Model isotherm } & \multicolumn{5}{|c|}{ Bentonite percentages onto sand/bentonite mixtures } \\
\hline & $0 \%$ & $2 \%$ & $6 \%$ & $8 \%$ & $12 \%$ \\
\hline \multicolumn{6}{|l|}{ Langmuir } \\
\hline $\mathrm{q}_{\mathrm{m}}\left(\mathrm{mg} \mathrm{g}^{-1}\right)$ & $-5.7 \times 10^{-3}$ & 38.462 & 1.164 & 0.628 & 0.482 \\
\hline $\mathrm{b}\left(\mathrm{L} \mathrm{mg}^{-1}\right)$ & -0.067 & $6.5 \times 10^{-3}$ & 0.245 & 0.510 & 0.766 \\
\hline $\mathrm{R}^{2}$ & 0.970 & 0.998 & 0.989 & 0.996 & 0.970 \\
\hline ERRSQ & 0.117 & $5.52 \times 10^{-3}$ & $2.09 \times 10^{-2}$ & $1.60 \times 10^{-3}$ & $2.37 \times 10^{-3}$ \\
\hline \multicolumn{6}{|l|}{ Freundlich } \\
\hline $1 / \mathrm{n}$ & 2.050 & 1.009 & 0.623 & 0.376 & 0.266 \\
\hline $\mathrm{K}_{\mathrm{F}}\left(\mathrm{mg} \mathrm{g}^{-1} /\left(\mathrm{mg} \mathrm{L}^{-1}\right)^{1 / \mathrm{n}}\right)$ & $1.64 \times 10^{-4}$ & 0.247 & 0.224 & 0.218 & 0.223 \\
\hline $\mathrm{R}^{2}$ & 0.998 & 0.998 & 0.989 & 0.949 & 0.844 \\
\hline ERRSQ & $2.98 \times 10^{-6}$ & $8.54 \times 10^{-4}$ & $1.56 \times 10^{-2}$ & $5.33 \times 10^{-3}$ & $7.17 \times 10^{-3}$ \\
\hline
\end{tabular}

The adsorption isotherms were obtained by considering the same conditions as above. The concentration $\mathrm{C}_{\mathrm{o}}$ was in the range of $(2.5-22 \mathrm{mg}$ $\mathrm{L}^{-1}$ ) while the bentonite ratios in the sand/bentonite mixtures were $2 \%, 6 \%, 8 \%$ and $12 \%$. The adsorbed amount at equilibrium $\mathrm{q}_{\mathrm{e}}\left(\mathrm{mg} \mathrm{g}^{-1}\right)$ was calculated from the following equation:

$$
\mathrm{q}_{\mathrm{e}}=\frac{\left(\mathrm{C}_{\mathrm{O}}-\mathrm{C}_{\mathrm{e}}\right) \mathrm{V}}{\mathrm{W}}
$$

where: $C_{e}$ is the equilibrium concentration of naphthalene $\left(\mathrm{mg} \mathrm{L}^{-1}\right)$.

The isotherm results were analyzed using the Langmuir and Freundlich models [35, 36] mathematically expressed as:

$$
\begin{aligned}
& \mathrm{q}_{\mathrm{e}}=\frac{\mathrm{q}_{\mathrm{m}} \mathrm{bC}_{\mathrm{e}}}{\left(1+\mathrm{bC}_{\mathrm{e}}\right)} \\
& \mathrm{q}_{\mathrm{e}}=\mathrm{K}_{\mathrm{F}} \mathrm{C}_{\mathrm{e}}{ }^{1 / \mathrm{n}}
\end{aligned}
$$

The Langmuir constants $\mathrm{q}_{\mathrm{m}}\left(\mathrm{mg} \mathrm{g}^{-1}\right)$ and $\mathrm{b}(\mathrm{L}$ $\mathrm{mg}^{-1}$ ), are the maximum amount of adsorbed naphthalene and the sorption equilibrium constant, respectively. $\mathrm{K}_{\mathrm{F}}\left(\mathrm{mg} \mathrm{g}^{-1} /\left(\mathrm{mg} \mathrm{L}^{-1}\right)^{1 / n}\right)$ and $\mathrm{n}$ are the constants of Freundlich related to the adsorption capacity and adsorption intensity, respectively. The linearized forms of both equations are:

$$
\begin{aligned}
& \frac{1}{\mathrm{q}_{\mathrm{e}}}=\frac{1}{\mathrm{q}_{\mathrm{m}} \mathrm{bC}_{\mathrm{e}}}+\frac{1}{\mathrm{q}_{\mathrm{m}}} \\
& \ln \left(\mathrm{q}_{\mathrm{e}}\right)=\ln \left(\mathrm{K}_{\mathrm{F}}\right)+\left(\frac{1}{\mathrm{n}}\right) \ln \left(\mathrm{C}_{\mathrm{e}}\right)
\end{aligned}
$$

The correlation coefficient $\left(\mathrm{R}^{2}\right)$ and the sum of square errors (ERRSQ) were used for testing the isotherm models. ERRSQ is represented by the following equation [37]: where: $\mathrm{P}$ is the number of experimental data points, $\mathrm{q}_{\mathrm{e}, \mathrm{m}}$ and $\mathrm{q}_{\mathrm{e}, \text { meas }}$ the equilibrium amounts of adsorption obtained from isotherm model and experiments data, respectively.

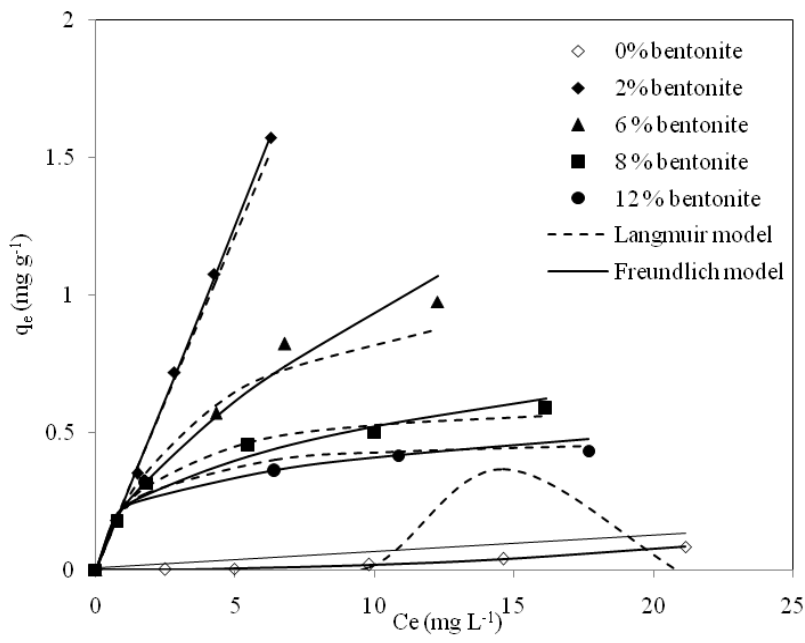

Fig. 7. Adsorption isotherms of naphthalene onto sand/bentonite mixtures.

The Langmuir and Freundlich coefficients are summarized in Table 5. The obtained isotherms at different percentages of bentonite in the sand/bentonite mixtures are illustrated in Fig. 7. According to $\mathrm{R}^{2}$ and ERRSQ values (Table 5), it appears that the most appropriate isotherm depends on the bentonite ratio. For the pure sand, 1/n>1 indicates an unfavorable adsorption. The aberrant values of the Langmuir parameters $\left(\mathrm{q}_{\mathrm{m}}=-5.7 \times 10^{-3}\right.$ $\mathrm{mg} \mathrm{g}^{-1}$ and $\mathrm{b}=-0.067 \mathrm{~L} \mathrm{mg}^{-1}$ ) clearly show that these data cannot be described by the Langmuir equation.

As illustrated in Fig. 7 and Table 5, the addition of $2 \%$ of bentonite (optimal fraction) in the sand/bentonite mixture greatly increases the 
S. Rennane et al.: Comparative removal of naphthalene by adsorption on different sand/bentonite mixtures naphthalene adsorption. Both the Freundlich and Langmuir models show high coefficients $\mathrm{R}^{2}$. The lower ERRSQ value obtained by the Freundlich model (linear isotherm $\mathrm{n} \approx 1$ ), reveals a slight predominance of this model with a distribution coefficient $\left(\mathrm{K}_{\mathrm{d}}\right)$. The results obtained for $6 \%$ of bentonite (Table 5), indicate that the adsorption data fit well the Freundlich model. For $2 \%$ and $6 \%$ bentonite, the distribution coefficients practically indicate that the adsorption phenomenon is governed by the adsorption intensity. The maximum amounts of adsorbed naphthalene obtained from Eq. 7 are $1.58 \mathrm{mg} \mathrm{g}^{-1}$ (2\% bentonite) and $1.07 \mathrm{mg} \mathrm{g}^{-1}(6 \%)$.

The Langmuir monolayer model (Fig. 7) appears to be the most appropriate for the highest percentages of bentonite ( $8 \%$ to $12 \%$ ). This is due to the rapid formation of the boundary layer which stops the transfer of adsorbate molecules to the solid surface and consequently prevents multilayer formation (characteristic of Freundlich model). Table 5 shows that the maximum amount of naphthalene decreases with increasing the percentage of bentonite $\left(0.628 \mathrm{mg} \mathrm{g}^{-1}\right.$ for $8 \%$ and $0.428 \mathrm{mg} \mathrm{g}^{-1}$ for $12 \%$ ). Several works on the naphthalene adsorption onto different clays and adsorbents, involved linear and non-linear models such as: linear model [38-40], Freundlich model [21, 34, 41] and Langmuir model [42, 43].

\section{Adsorption kinetics}

The adsorption kinetics is useful for elucidating the adsorption mechanism. In this study, four kinetic models, including pseudo-first order, pseudo-second order, Elovich and intraparticle diffusion were used to investigate the adsorption of naphthalene on sand/bentonite mixture.

The pseudo-first-order equation is given by Lagergren [44]:

$$
\ln \left(\mathrm{q}_{\mathrm{e}}-\mathrm{q}_{\mathrm{t}}\right)=\ln \left(\mathrm{q}_{\mathrm{e}}\right)-\mathrm{k}_{1} \mathrm{t}
$$

where $\mathrm{q}_{\mathrm{e}}$ and $\mathrm{q}_{\mathrm{t}}\left(\mathrm{mg} \mathrm{g}^{-1}\right)$ are the amounts of naphthalene adsorbed onto the mixture sand/bentonite at equilibrium and at time $\mathrm{t}$, respectively and $\mathrm{k}_{1}$ the rate constant $\left(\mathrm{min}^{-1}\right)$.

The pseudo-second-order model is expressed by the following equation [45]:

$$
\frac{\mathrm{t}}{\mathrm{q}_{\mathrm{t}}}=\frac{1}{\mathrm{k}_{2} \mathrm{q}_{\mathrm{e}}^{2}}+\frac{1}{\mathrm{q}_{\mathrm{e}}} \mathrm{t}
$$

where $\mathrm{k}_{2}$ is the rate constant $\left(\mathrm{g} \mathrm{mg}^{-1} \mathrm{~min}^{-1}\right)$.

The Elovich equation is generally expressed as follows [46, 47]:

$$
\frac{\mathrm{dq}_{\mathrm{t}}}{\mathrm{dt}}=\alpha \exp \left(-\beta \mathrm{q}_{\mathrm{t}}\right)
$$

To simplify the Elovich equation, Chien and Clayton [48] assumed $\alpha \beta t>1$. By applying the boundary conditions $\left(\mathrm{q}_{\mathrm{t}}=0\right.$ at $\mathrm{t}=0$ and $\mathrm{q}_{\mathrm{t}}=\mathrm{q}_{\mathrm{t}}$ at $\mathrm{t}=$ t), equation (11) becomes [49]:

$$
\mathrm{q}_{\mathrm{t}}=\frac{1}{\beta} \ln (\alpha \beta)+\frac{1}{\beta} \ln (\mathrm{t})
$$

where $\alpha$ is the initial adsorption rate $\left(\mathrm{mg} \mathrm{g}^{-1}\right.$ $\left.\min ^{-1}\right)$ and $\beta$ the desorption constant $\left(\mathrm{g} \mathrm{mg}^{-1}\right)$ for the Elovich model.

The straight-lines $\ln \left(\mathrm{q}_{\mathrm{e}}-\mathrm{q}_{\mathrm{t}}\right)$ vs. $\mathrm{t}$ for the pseudofirst-order model, $\mathrm{t} / \mathrm{q}_{\mathrm{t}} v s . \mathrm{t}$ for the pseudo-secondorder model, and the plots $\mathrm{q}_{\mathrm{t}} v s$. $\ln (\mathrm{t})$ for the Elovich model were plotted to obtain the kinetic parameters of the naphthalene adsorption onto sand/bentonite mixtures.

According to the high $\mathrm{R}^{2}$ values [0.977-1] (Table 6), the kinetics of naphthalene adsorption onto the sand/bentonite mixtures are well described by the pseudo-second-order model. Similar results of the retention of naphthalene have been reported using other adsorbents, namely the bentonite clay mineral [26], organo-sepiolite [50], natural and chemically modified bentonite [51] and activated carbons modified by microwave [12].

To determine the diffusibility of naphthalene molecules into the adsorbent pores, the WeberMorris intraparticle diffusion model was used (Eq. 13) $[52]:$

$$
\mathrm{q}_{\mathrm{t}}=\mathrm{k}_{\mathrm{p}} \mathrm{t}^{1 / 2}+\mathrm{C}
$$

where $\mathrm{k}_{\mathrm{p}}$ is the intraparticle diffusion rate ( $\mathrm{mg} \mathrm{g}$ $\mathrm{min}^{-1 / 2}$ ) and $\mathrm{C}$ the intercept (mg $\mathrm{g}^{-1}$ ) which is proportional to the boundary layer thickness. The intraparticle diffusion is the rate-controlling step if the plot of $\mathrm{q}_{\mathrm{t}}$ versus $\mathrm{t}^{1 / 2}$ gives a straight line passing by the origin. However, if the plot deviates from linearity, then the boundary layer diffusion (film diffusion) controls the sorption process.

The intraparticle diffusion plot for the naphthalene adsorption onto sand/bentonite mixtures at different initial concentrations (Fig. 8a, b) can be divided into different stages. The first linear stage is attributed to the values of $\mathrm{K}_{\mathrm{p}}$ and $\mathrm{C}$ are calculated from the slope and intercept of plots ( $\mathrm{q}_{\mathrm{t}}$ versus $\mathrm{t}^{1 / 2}$ ) of the second linear stage (Table 6). Transfer of naphthalene molecules from the solution toward the external surface of adsorbent; the second portion is the gradual adsorption stage, where the intraparticle diffusion is the rate controlling step. The third stage is attributed to the establishment of adsorption equilibrium. 
S. Rennane et al.: Comparative removal of naphthalene by adsorption on different sand/bentonite mixtures

Table 6. Kinetic model parameters for the adsorption of naphthalene onto sand/bentonite mixtures.

\begin{tabular}{|c|c|c|c|c|c|c|}
\hline & \multicolumn{2}{|c|}{$2.5 \mathrm{mg} \mathrm{L}^{-1}$} & \multicolumn{2}{|c|}{$5 \mathrm{mg} \mathrm{L}^{-1}$} & \multicolumn{2}{|c|}{$10 \mathrm{mg} \mathrm{L}^{-}$} \\
\hline Kinetic model & $2 \%$ & $2 \%$ & $6 \%$ & $8 \%$ & $12 \%$ & $2 \%$ \\
\hline \multicolumn{7}{|l|}{ Pseudo-first-order } \\
\hline$k_{l}\left(\min ^{-1}\right)$ & 0.125 & 0.165 & 0.328 & 0.908 & 0.976 & 0.195 \\
\hline$q_{e}\left(m g g^{-1}\right)$ & 0.136 & 0.267 & 0.297 & 0.261 & 0.248 & 0.594 \\
\hline$R^{2}$ & 0.957 & 0.956 & 0.986 & 0.967 & 0.952 & 0.981 \\
\hline \multicolumn{7}{|l|}{ Pseudo-second-order } \\
\hline$k_{2}\left(g m g^{-1} m^{-1}\right)$ & 1.705 & 1.094 & 1.066 & 6.973 & 9.443 & 0.516 \\
\hline$q_{e}\left(m g g^{-1}\right)$ & 0.194 & 0.384 & 0.387 & 0.338 & 0.336 & 0.792 \\
\hline$R^{2}$ & 0.977 & 0.979 & 0996 & 1 & 1 & 0.993 \\
\hline \multicolumn{7}{|l|}{ Elovich } \\
\hline$\left.\alpha \overline{\left(m g g^{-1} m i n\right.} n^{-1}\right)$ & 0.251 & 0.601 & 0.331 & 9.115 & 46.638 & 1.187 \\
\hline$\beta\left(g m g^{-1}\right)$ & 30.303 & 14.925 & 11.628 & 22.222 & 27.777 & 7.246 \\
\hline$R^{2}$ & 0.953 & 0.945 & 0.978 & 0.973 & 0.972 & 0.972 \\
\hline \multicolumn{7}{|l|}{ Intraparticle diffusion } \\
\hline$k_{p}\left(m g g^{-1} m^{-1 / 2}\right)$ & 0.029 & 0.064 & 0.053 & 0.054 & 0.044 & 0.130 \\
\hline$C\left(m g g^{-1}\right)$ & 0.047 & 0.095 & 0.141 & 0.189 & 0.216 & 0.196 \\
\hline$R^{2}$ & 0.996 & 0.991 & 0.988 & 0.919 & 0.917 & 0.992 \\
\hline
\end{tabular}

The values of $K_{p}$ and $C$ are calculated from the slope and intercept of plots $\left(\mathrm{q}_{\mathrm{t}}\right.$ versus $\left.\mathrm{t}^{1 / 2}\right)$ of the second linear stage (Table 6$)$. The values of $C(\neq 0)$ can be attributed to the difference in the mass transfer rate between the initial and final stages of adsorption [53], demonstrating that the intraparticle diffusion is not the only rate-controlling step during the naphthalene adsorption; this result was supported by several authors [12, 41].

The time elapsed during the intraparticle diffusion decreases with increasing the bentonite amount (Fig. 8a). It is evaluated at $14 \mathrm{~min}$ for $2 \%$ and 9 min for $6 \%$ and decreases for $12 \%$ bentonite. These results indicate that the time required for intraparticle diffusion is large compared with the global time.

The obtained values of $\mathrm{Kp}$ increase in the following order: $\mathrm{kp}(12 \%)<\mathrm{Kp}(8 \%)<\mathrm{Kp}(6 \%)$ $<\mathrm{Kp}(2 \%)$ for the effect of bentonite percentage (Table 6) and in the order of: $\mathrm{Kp}\left(2.5 \mathrm{mg} \mathrm{L}^{-1}\right)<\mathrm{Kp}$ $\left.(5 \mathrm{mg} \mathrm{L})^{-1}\right)<\mathrm{Kp}\left(10 \mathrm{mg} \mathrm{L}^{-1}\right)$ for the effect of naphthalene concentration $\mathrm{C}_{0}$. On the other hand, the intercept increases with both the percentage of bentonite and naphthalene concentration $\mathrm{C}_{\mathrm{o}}$. The lowest values are obtained for $2 \%$ bentonite (optimal fraction) and low initial concentration of naphthalene $\left(2.5 \mathrm{mg} \mathrm{L}^{-1}\right)$, indicating a small film resistance to the mass transfer surrounding the adsorbent particle. The $\mathrm{R}^{2}$ values indicate that the intraparticle diffusion model is more suitable for the low bentonite percentages $\left(\mathrm{R}^{2}(2 \%)=0.999\right.$ and $\left.\mathrm{R}^{2}(6 \%)=0.988\right)$ in comparison with other percentages $\left(R^{2}(8 \%)=0.91\right.$ and $\left.R^{2}(12 \%)=0.91\right)$.

\section{Effect of temperature and thermodynamic study}

The effect of temperature on the naphthalene adsorption onto the sand/bentonite mixture at optimal fraction ( $2 \%$ of bentonite) was investigated at 10, 20 and $30^{\circ} \mathrm{C}$ (Table 7). The thermodynamic parameters for the adsorption process; free energy change $\left(\Delta \mathrm{G}^{\circ}\right)$, enthalpy change $\left(\Delta \mathrm{H}^{\circ}\right)$, and entropy change $\left(\Delta \mathrm{S}^{\circ}\right)$, were calculated using the following equations:

$$
\begin{aligned}
& \Delta \mathrm{G}^{\circ}=-\mathrm{RT} \ln \mathrm{K}_{\mathrm{d}} \\
& \ln \mathrm{K}_{\mathrm{d}}=\frac{\Delta \mathrm{S}^{\circ}}{\mathrm{R}}-\frac{\Delta \mathrm{H}^{\circ}}{\mathrm{RT}}
\end{aligned}
$$

$K_{d}, R$, and $T$ are: the distribution coefficient of the adsorbate $\left(\mathrm{q}_{\mathrm{e}} / \mathrm{C}_{\mathrm{e}}\right)$, the universal gas constant $\left(8.314 \mathrm{~J} \mathrm{~K}^{-1} \mathrm{~mol}^{-1}\right)$ and the absolute temperature $(\mathrm{K})$, respectively.

Table 7 shows that the amount of adsorbed naphthalene increases with increasing temperature. The $\Delta \mathrm{H}^{\circ}$ and $\Delta \mathrm{S}^{\circ}$ values were computed from the slope and intercept of the plot $\ln \mathrm{K}_{\mathrm{d}}$ versus $1 / \mathrm{T}$, while $\Delta \mathrm{G}^{\circ}$ was calculated at different temperatures and is shown in Table 7. The positive values of $\Delta \mathrm{H}^{\circ}$ and $\Delta \mathrm{S}^{\circ}$ suggest an endothermic reaction and increase in randomness at the solid-liquid interface during the adsorption. The negative value of $\Delta \mathrm{G}^{\circ}$ indicates a spontaneous nature of adsorption process. The decrease in $\Delta \mathrm{G}^{\circ}$ with increasing temperature $\left(-28.72\right.$ to $\left.-30.751 \mathrm{~kJ} \mathrm{~mol}^{-1}\right)$ indicates that the adsorption of naphthalene on the sand/bentonite mixture is more favorable at higher temperature $\left(30^{\circ} \mathrm{C}\right)$.

The activation energy $\left(\mathrm{E}_{\mathrm{a}}, \mathrm{kJ} \mathrm{mol}^{-1}\right)$ of adsorption is determined from the Arrhenius law in the studied temperature range: 


\section{S. Rennane et al.: Comparative removal of naphthalene by adsorption on different sand/bentonite mixtures}

$$
\ln \mathrm{k}_{2}=\ln \mathrm{A}-\frac{\mathrm{E}_{\mathrm{a}}}{\mathrm{RT}}
$$

where $\mathrm{A}$ is the pre-exponential factor, and $\mathrm{k}_{2}$ the value of the pseudo-second-order. The activation energy $\left(E_{a}\right)$ is deduced from the straight line $\operatorname{lnk}_{2}$

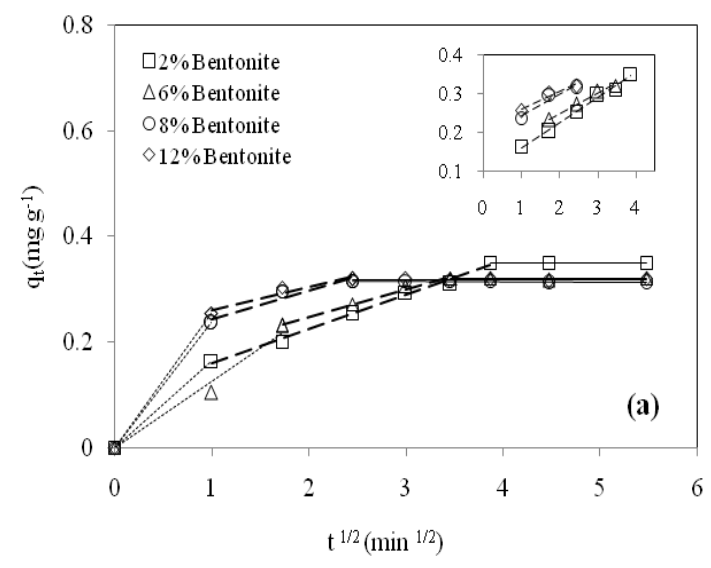
against reciprocal temperature (Table 7$)$. The low energy $E_{a}$ is in the range $\left(5-40 \mathrm{~kJ} \mathrm{~mol}^{-1}\right)$, indicating that naphthalene is physisorbed [54]. Therefore, the affinity of bentonite for naphthalene molecules may be ascribed to Van der Waals forces and electrostatic attractions with the clay surface.

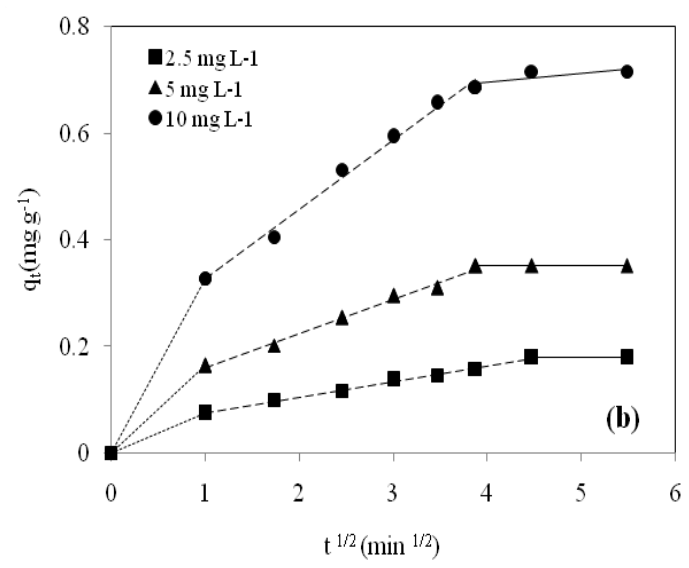

Fig. 8. Intraparticle diffusion plots for naphthalene adsorption: (a) at different bentonite ratios, (b) at different initial concentrations.

Table 7. Thermodynamic parameters for adsorption of naphthalene onto the sand/bentonite mixture.

\begin{tabular}{cccccccc}
\hline $\begin{array}{c}\mathrm{T} \\
\left({ }^{\circ} \mathrm{C}\right)\end{array}$ & $\begin{array}{c}\mathrm{q}_{\mathrm{e}} \\
\left(\mathrm{mg} \mathrm{g}^{-1}\right)\end{array}$ & $\begin{array}{c}\mathrm{K}_{\mathrm{d}} \\
\left(\mathrm{L} \mathrm{g}^{-1}\right)\end{array}$ & $\begin{array}{c}\mathrm{k}_{2} \\
\left(\mathrm{gmg}^{-1} \mathrm{~min}^{-1}\right)\end{array}$ & $\begin{array}{c}\Delta \mathrm{H}^{\circ} \\
\left(\mathrm{kJ} \mathrm{mol}^{-1}\right)\end{array}$ & $\begin{array}{c}\Delta \mathrm{S}^{\circ} \\
\left(\mathrm{J} \mathrm{K}^{-1} \mathrm{~mol}^{-1}\right)\end{array}$ & $\begin{array}{c}\Delta \mathrm{G}^{\circ} \\
\left(\mathrm{kJ} \mathrm{mol}^{-1}\right)\end{array}$ & $\begin{array}{c}\mathrm{E}_{\mathrm{a}} \\
\left(\mathrm{kJ} \mathrm{mol}^{-1}\right)\end{array}$ \\
\hline 10 & 0.272 & 0.165 & 0.930 & - & - & -28.720 & - \\
20 & 0.350 & 0.247 & 1.094 & 32.95 & 101.597 & -29.735 & 8.263 \\
30 & 0.447 & 0.482 & 1.171 & - & - & -30.751 & - \\
\hline
\end{tabular}

\section{CONCLUSION}

Based on detailed studies carried on the naphthalene adsorption at different initial concentrations and on different sand/bentonite mixtures, it was found that the adsorbed amount of naphthalene increased with increasing the initial concentration and decreasing the bentonite percentage. The maximum yield of adsorption (71\%) was found by adding $2 \%$ of bentonite to the sand/bentonite mixture. This result was consolidated by SEM analysis that showed the remarkable effect of the very low bentonite content on the sand structure. The isotherm model describing the naphthalene adsorption on bentonite mixtures was presented.

The optimal ratio of bentonite $(2 \%)$ was well fitted by the Freundlich model with a constant $\mathrm{K}_{\mathrm{d}}$ of $0.247 \mathrm{~L} \mathrm{~g}^{-1}$. The kinetic data were well represented by the pseudo-second-order model. The intraparticle diffusion plays an important role, but cannot be considered as the sole limiting step during the adsorption process. The thermodynamic parameters indicated a spontaneous and endothermic nature of the naphthalene adsorption. The low activation energy $E_{a}$ is characteristic of a physical adsorption of naphthalene. All these results show that the sand/bentonite mixture can be a promising adsorbent for the removal of naphthalene from wastewaters.

\section{REFERENCES}

1. C. J. Halsall, P. J. Coleman, B. J. Davis, V. Burnett, K. S. Waterhouse, P. Harding-Jones, K. C. Jones, Environ. Sci. Technol. 28, 2380 (1994).

2. S. M. Bamforth, I. Singleton, Chem.Technol. Biotechnol., 80, 723 (2005).

3. S. E. Agarry, O. O. Ogunleye, O. A. Aworanti, Environ.Technol., 34, 825 (2013).

4. U.S. Environmental Protection Agency, Health effects assessment for naphthalene, EPA/540/1D86/ 014. Cincinnati, OH: Environmental Criteria and Assessment Office, Office of Health and Environmental Assessment, Office of Research and Development, 1986.

5. T. Ohno, K. Tokieda, S. Higashida, M. Matsumura, Appl. Catal. A. General, 244, 383 (2003).

6. Z. Liu, A. M. Jacobson, R. G. Luthy, Appl. Environ. Microbiol., 61, 145 (1995).

7. W. J. Cooper, M. G. Nickelsen, R. V. Green, S. P. Mezyk, Rad. Phys. Chem., 65, 571 (2002).

8. B. Legube, S. Guyon, H. Sugimitsu, M. Dore, Ozonation of naphthalene in aqueous solution-I: 
S. Rennane et al.: Comparative removal of naphthalene by adsorption on different sand/bentonite mixtures ozone consumption and ozonation products, Water Res., 20, 197 (1986).

9. C. F. Chang, C.Y. Chang, K. H. Chen, W.T. Tsai, J. L. Shie, H. Chen, J. Colloid Interface Sci., 277, 29 (2004).

10. C. O. Ania, B. Cabal, C. Pevida, A. Arenillas, J. B. Parra, F. Rubiera, J. J. Pis, Water Res., 41, 333 (2007).

11. X. Y. Ge, F. Tian, Z. L.Wu,Y. J. Yan, G. Cravotto, Z. S. Wu, Chem. Eng. Process., 91, 67 (2015).

12. D. Liu, Z. S. Wu, X.Y. Ge, G. Cravotto, Z. Wu, Y. Yan, J Taiwan Inst. Chem. Eng., 59, 563 (2016).

13. C. Valderrama, X. Gamisans, X. de las Heras, A. Farran, J. L Cortina, J. Hazard. Mater., 157, 386 (2008).

14. S.A.S. Mohammed, M. Naik, Int. J. Ecol. Dev., 19, 15 (2011).

15. D. E. Daniel, J. Geotech. Eng., 110, 285 (1984).

16. K. S. King, R. M. Quigley, F. Fernandez, D. W. Reades, A. Bacopoulos, Canad. Geotech. J., 30, 124 (1993).

17. J. H. Kleppe, R. E. Olson, Hydraulic Barriers in Soil and Rock ASTM STP, 874, 263 (1985).

18. S. Lamichhane, K.C. Bal Krishna, R. Sarukkalige, Chemosphere, 148, 336 (2016).

19. T. Chalermyanont, S. Arrykul, J. Sci. Technol., 27, 313 (2005).

20. J. K. Mitchell, Fundamentals of Soil Behaviour, second edn., John Wiley, New York, 1993.

21. A. Kapoor, T. Viraraghavan, J. Environ. Eng., 124, 1020 (1998).

22. F. Barbier, G. Duc, M. Petit-Ramel, Colloids Surf. A., 166, 153 (2000).

23. S. Al-Asheh, F. Banat, L. Abu-Aitah, Sep. Purif. Technol., 33, 1 (2003).

24. A. Kaya, J. Environ. Eng., 130, 918 (2004).

25. L. Zhu, R. Zhu, Fresenius Environ. Bull., 20, 521 (2011).

26. C. Obi, I.P. Okoye, J. Appl. Sci. Environ. Manage., 18, 143 (2014).

27. R. Proia, P. Croce, G. Modoni, Procedia Engineering, 158, 51 (2016).

28. T. C. Kenney, W. A. Van Veen, M. A. Swallow, M. A. Sungalia, Canad. Geotech. J., 29, 364 (1992).

29. S. Justyna, S. Zuzanna, C. Paweł, P. Agnieszka, J. Res. Appl. Agric., 60, 98 (2015).

30. M. Debieche, F. Kaoua, Mater. Sci. Appl., 5, 347 (2014).

31. J. C. Appert-Collin, S. Dridi-Dhaouadi, M. O. Simonno, M. Sardin, Phys. Chem. Earth, 24, 543 (1999).

32. L.C. Lin, C.H. Benson, J. Geotech. Geoenviron. Eng., 123, 402 (2000).

33. X. Y. Ge, X. Ma, Z. S. Wu, X. Xiao,Y. Yan, Res. Chem. Intermed., 41, 7327 (2015).

34. S. Sener, A. Ozy1lmaz, Ultrasonics Sonochem., 17, 932 (2010).

35. I. Langmuir, J. Am. Chem. Soc., 40, 1361 (1918).

36. H. Freundlich, Z. Phys. Chem., 57A, 384 (1906).

37. K.V. Kumar, S. Sivanesan, Hazard. Mater., 36, 721 (2006).

38. Y. El-Nahhal, J. Safi, J. Food Agri. Environ., 3, 295 (2005).

39. B. Chen, W. Huang, J. Mao, Lv. Shaofang, J. Hazard. Mater., 158, 116 (2008).

40. S. Changchaivong, S. Khaodhiar, Appl. Clay Sci., 43, 317 (2009).

41. R. Abu-Elella, M. E. Ossman, M. Abd-Elfatah, A. Elgendi, Desalin. Water Treat., 51, 3472 (2013).

42. S. E. Moradi, Chem. Biochem. Eng., 27, 365 (2013).

43. A. Balati, A. Shahbazi, M. Amini, S. H. Hashemi, K. Jadidi, Eur. J. Environ. Sci., 4, 69 (2014).

44. S. Lagergren, Kungliga Svenska Vetenskapsakademiens, Handlingar, 24, 1 (1898).

45. Y.S. Ho, G. McKay, Process. Saf. Environ. Protect., 76, 183 (1998).

46. S. J. Elovich, in: Proceedings of the Second International Congress of Surface Activity, Butterworths Scientific Publications, London, 1957, p. 252.

47. M.J.D. Low, Chem. Rev., 60, 267 (1960).

48. S. H. Chien, W. R. Clayton, Soil Sci. Soc. Am. J., 44, 265 (1980).

49. D. L. Sparks, Kinetics and mechanisms of chemical reactions at the soil mineral/water interface, Soil Phys. Chem., D.L. Sparks (ed.), $2^{\text {nd }}$ edn., CRC Press, Boca Raton, 1999, p. 135.

50. Ö. Gök, A .S. Özcan, A. Özcan, Desalination, 220, 96 (2008).

51. E. M. Ö. Kaya, A. S. Özcan, Ö. Gök, A. Özcan, Adsorption, 19, 879 (2013).

52. W. J. Jr. Weber, J. C. Morris, J. Sanit. Eng. Div. Proceed. Am. Soc. Civil Eng., 89, 31 (1963).

53. H. Koyuncu, Appl. Clay. Sci., 38, 279 (2008).

54. M. E. Argun, J. Hazard. Mater., 1(50), 587 (2008). 